\title{
Canadian Wildlife Service Reductions: Response of Minister
}

Thank you for your letter of December 10, 1984, regarding reductions in the Canadian Wildlife Service. While I can certainly sympathize with your concern, I would like to. mention, however, that in each of the past ten years, the expenditures of the federal government have exceeded its revenue. These continuing deficits have led to enormous growth in the burden of debt and the costs of servicing that debt. Unless we begin to put our financial house in order, the burden of debt will continue to mount rapidly in the future.

In order to maximize and make the most efficient use of our resources, I have examined programs and their relationship to the mandate of this Department. In this determination, we have closely examined the activities of the Canadian Wildlife Service in order that they stick closely to their responsibility for migratory birds, endangered species, and our international obligations. We wish to continue and improve upon the outstanding work in the above areas that the Canadian Wildlife Service has done over the past number of years. While we are reviewing our expenditures and examining areas of internal efficiencies, we are searching for ways of providing more mandate-related services with current resources, although we must slow the rapid expansion of the past to allow us the opportunity to be better able to direct our resources.

The Wildlife Interpretation Centres provide an important opportunity for Canadians to understand their Wildlife Heritage as well as providing tourist benefits to local residents. But they are not directly essential to our mandate. Furthermore, they lend themselves well to local management and operation. I have already been in touch with my provincial colleagues and with local organizations and groups interested in managing these centres, and I am hopeful that they will be able to assist us in keeping them open. It does indeed provide a new opportunity for local and private initiative, and already a number of groups have expressed interest in managing the operation of those centres across the country.

This government is committed to maintaining environmental quality as well as diverse and abundant wildlife resources. Wildlife research will not be discontinued in Canada after these reductions; it is continuing in universities, provinces, as well as in the private sector. These reductions themselves only amount to $5.1 \%$ of our total departmental work-force. We will retain a vital and effective Canadian Wildlife Service with a well-defined mandate. This service will have some 300 persons across Canada and an annual budget of approximately 20 million dollars. Not all research in national parks will be eliminated. Although the reductions in the Canadian Wildlife Service will affect some research in western and northern national parks, alternative means, such as the use of private consultants and universities, are being examined to ensure that Parks Canada's research requirements are met.

For those employees who are affected by these reductions, every effort has been made by the department and will continue to be made to secure alternate employment elsewhere in the Public Service. I hope that these explanations put the reductions into perspective for you and clearly state to you that this government has a strong commitment towards environment and protection of wildlife.

[Signed: Yours sincerely, etc.]

Suzanne Blais-Grenier, Minister Environment Canada

Ottawa

Ontario $\mathrm{KIAOH}$

Canada.

\section{Third World May Seize Foreign Assets}

Less-developed nations will not only default on their international debts but are likely to expropriate foreignowned property, according to Professor Jay W. Forrester, of Massachusetts Institute of Technology, whose computer simulations of the operations of the world economy resulted in the widely discussed 'Limits to Growth' study, and who now offers this assessment in a report on his computer studies of the US economy.

Professor Forrester claims that his studies have confirmed the existence of a long-term economic cycle in the world economy. The 45 - to 60 -years cycle hit a low point in the 1920 s and early 1930s, and is approaching another low point now, Forrester writes in the June issue of The Futurist magazine, published by the World Future Society (address below). One result is that foreign nations 'are likely to default on debts totalling more than the net worth of the entire American banking system.'

'Even now, at the top of a business cycle, developing nations are barely able to pay the interest on their loans, let alone pay off the principal,' Forrester writes. 'The next downturn will cause them even greater difficulty.'

'To meet their payments, countries would be forced to demand greater economic austerity than their citizens will tolerate. The result will almost certainly be changes in governments. New governments will say, "We didn't take on the debt. We don't have responsibility for it..." '. When
'Once countries have defaulted and their credit is ruined, there is no reason why they shouldn't expropriate the assets of the multinational companies in their countries, as was done in the late 1930s,' Forrester writes.

The US Government's debt is now 'on the verge of a runaway compounding situation,' says Forrester. 'If the deficit is not brought under control, it will rapidly get out of hand, with no solution available except for the United States to default on its debt.'

As the long wave becomes better understood, says Forrester, governments will be willing to follow the policies required to forestall its most painful consequences. But after the downturn bottoms out, Forrester believes, the economy will move upwards again. Within a decade, there will be a major shift in the nature of the nation's capital plant (factories, equipment, etc.) after the present plant has worn out and depreciated. A new upswing will be under way.

\author{
ANDREW LAWLER \\ World Future Society \\ 4916 St Elmo Avenue \\ Bethesda \\ Maryland 20814 \\ USA.
}

